\title{
PENGGUNAAN CAMPUR KODE DAN ALIH KODE DALAM TRANSAKSI JUAL BELI PEDAGANG KAKI LIMA DI CIREBON
}

\author{
Hesti Muliawati $^{1),}$ Solikhin $^{2),}$ dan Ulfa Nursyamsiah ${ }^{3)}$ \\ Universitas Swadaya Gunung Jati Cirebon \\ hestimuliawati@yahoo.com,solikhin131096@gmail.com,ulfanursyamsiah@gmail.com
}

\begin{abstract}
ABSTRAK
Masyarakat Indonesia tergolong masyarakat tutur dwibahasawan. Bagi sebagian masyarakat hal yang biasa menggunakan campur kode bahkan alih kode karena bahasa pertamanya ialah bahasa daerah dan bahasa keduanya yakni bahasa Indonesia. Penelitian ini bertujuan untuk mendeskripsikan alih kode dan campur kode yang terjadi dalam kegiatan jual beli serta faktorfaktor apa saja yang mempengaruhi kejadian tersebut. Data penelitian ini adalah berupa variasi bahasa yang digunakan oleh pedagang kaki lima di Jalan Perjuangan, Kota Cirebon saat melakukan transaksi jual beli antara penjual dan pembeli. Adapun sumber penelitian yakni pedagang kaki lima yang berada di Jalan Perjuangan, Kota Cirebon yang berada di sekitar empat lokasi berbeda. Dalam kenyataan sehari-hari, ternyata bahwa ragam bahasa lebih cenderung memakai alih kode dan campur kode. Penggunaan campur kode dan alih kode dalam percakapan antara penjual dan pembeli berfungsi sebagai pengakrab dan mempermudah dalam berkomunikasi. Dengan demikian, campur kode dan alih kode sering terjadi dan digunakan saat berkomunikasi dalam transaksi jual beli.
\end{abstract}

Kata kunci: Alih Kode, Campur Kode, Ragam bahasa jual beli

\section{A. PENDAHULUAN}

Komunikasi antar kelompok masyarakat biasanya menggunakan bahasa Indonesia dan juga bahasa daerah bagi mereka yang sudah akrab. Tidak dipungkiri bahwa masyarakat Indonesia tergolong dwibahasawan. Bagi sebagian besar masyarakat Indonesia bahasa daerah merupakan bahasa pertama dan bahasa Indonesia merupakan bahasa kedua. Jika mereka hanya menguasai satu bahasa saja, mereka akan merasa kesulitan dalam berkomunikasi dengan orang-orang yang tidak bisa berbahasa yang sama dengan mereka. Keadaan inilah yang menjadikan bahasa Indonesia berkembang dalam hal fungsi dan kedudukannya.

Bahasa Indonesia yang digunakan di tempat-tempat umum itu cenderung terkesan sebagai bahasa Indonesia kedaerahan dan ragam santai. Artinya, mereka memakai bahasa Indonesia dengan dialek daerah masing-masing, misalnya bahasa Indonesia dialek Cirebon, bahasa Indonesia dialek Sunda, bahasa Indonesia dialek Tegal, bahasa Indonesia dialek Brebes, dll.

Namun, diantara penutur dengan dialek yang berbeda itu dapat saling mengerti apabila sedang berkomunikasi. Tingkat penguasaan bahasa Indonesia antara orang yang satu dan orang yang lain 


\section{DEIKSIS - JURNAL PENDIDIKAN BAHASA DAN SASTRA INDONESIA}

berbeda-beda karena memperoleh bahasa Indonesia atau bahasa kedua pada mereka tidak sama. Diantaranya ada yang betulbetul belajar menguasai bahasa Indonesia secara tepat, antara lain melalui lembaga pendidikan, tetapi banyak juga dari mereka yang menggunakan bahasa Indonesia dengan mengabaikan kaidah pemakaian bahasa yang ada.

Dengan demikian, batasan pembicaraan tentang alih kode dan campur kode dalam penelitian ini adalah pada wacana jual-beli pedagang kaki lima di sekitar Jalan Perjuangan, Cirebon. Dipilihnya lokasi tersebut dikarenakan disanalah peristiwa tawar menawar dalam transaksi jual-beli masih terjadi. Sesuai dengan latar belakang masalah tersebut, rumusan masalah penelitian ini yaitu: 1) alih kode apa saja yang terdapat di dalam wacana interaksi pedagang kaki lima?; 2) campur kode apa saja yang terdapat di dalam wacana interaksi pedagang kai lima?; 3) faktorfaktor apa saja yang menyebabkan timbulnya alih kode dan campur kode di dalam wacana interaksi pedagang kai lima?; dan 4) fungsi apa saja yang diperankan oleh alih kode dan campur kode di dalam wacana interaksi pedagang kaki lima?

\section{B. KAJIAN TEORETIS}

Hakikatnya bahasa mempunyai fungsi tersendiri sesuai dengan situasi yang melatarbelakanginya. Pertukaran pemakaian bahasa dapat menimbulkan gangguan komunikasi (Chaer dan Agustina, 2010: 122). Maksudnya pemakaian bahasa disesuaikan dengan tuntutan ragamnya. Pada situasi resmi seseorang diharapkan dapat menggunakan bahasa dalam ragam formal, sebaliknya pada situasi yang akrab seseorang selayaknya menggunakan bahasa dalam ragam informal. Berbicara mengenai ragam bahasa, peristiwa tutur pada pedagang pada dasarnya dapat digolongkan ke dalam ragam bahasa usaha. Tuturan ragam bahasa usaha biasanya berbentuk ringkas. Dengan tuturan ringkas tersebut, komunikasi antara penjual dan pembeli, baik yang sudah dikenal maupun yang belum akan terasa akrab. Selanjutnya, situasi tutur yang demikian sebetulnya dapat dimanfaatkan oleh pedagang untuk menarik minat pembeli terhadap barang dagangannya.

Akibatnya, interaksi antara pedagang atau penjual dan pembeli sangat kompleks dan beragam. Keberagaman interaksi tersebut pun tercermin dalam hal pemilihan dan penggunaan bahasa yang tak hanya satu bahasa. Hal inilah yang mengakibatkan munculnya alih kode dan campur kode dalam tuturan para pedagang dan pembeli. Pada masyarakat tutur yang demikian cukup relevan dan menarik untuk diteliti dan deskripsikan pemakaian bahasanya, khususnya yang menyangkut masalah alih kode dan campur kode. Dikatakan menarik karena dalam masyarakat seperti itu dimungkinkan sering terjadi perpindahan alih kode dan campur kode dalam peristiwa tutur antar bahasanya.

Penelitian ini menempatkan pada salah satu ranah yaitu ranah transaksi. Dipilihnya ranah ini karena transaksi terjadinya kontak antara masyarakat tutur dengan segala lapisan dan golongan. Ranah transaksi sebagai ranah yang didalamnya terjadi peristiwa transaksi jual beli barang 


\section{DEIKSIS - JURNAL PENDIDIKAN BAHASA DAN SASTRA INDONESIA}

dan jasa, khususnya peristiwa tawar menawar antara penjual dan pembeli (Sumarsono, 2009: 206 -207).

Dengan mengacu kepada batasan di atas, dapatlah dikatakan bahwa transaksi dapat dibatasi sebagai peristiwa dalam kegiatan jual-beli barang, khususnya yang menyangkut aktivitas tawar-menawar. Pada dasarnya alih kode merupakan penggantian kode yang berupa bahasa atau ragam bahasa dari kode yang satu ke kode yang lain pada waktu seseorang bertutur.

Menurut Kridalaksana (1982: 19), pengertian penggantian yang dimaksudkan untuk menyesuaikan diri dengan peran serta atau situasi lain.

\section{METODOLOGI PENELITIAN}

Metode yang digunakan adalah metode deskriptif kualitatif. Tujuan penggunaan metode ini yaitu untuk mendeskripsikan bagaimana penggunaan dan pemilihan bahasa yang digunakan oleh pedagang kaki lima di Jalan Perjuangan dalam transaksi jual beli.

Adapun teknik pengumpulan data yang digunakan penyadapan serta wawancara. Metode observasi ini juga digunakan untuk mengungkap penggunaan bahasa dalam konteks jual beli antara pedagang dan pembeli di sekitar Jalan Perjuangan, Kota Cirebon.

Teknik pengumpulan data yang digunakan peneliti yaitu penyadapan serta wawancara yang berisi rekaman kegiatan jual beli antara pembeli dan pedagang. Teknik ini dipakai dikarenakan peneliti tidak terlibat dalam menentukan, pembentukan, dan pemunculan calon data karena hanya berperan sebagai pengamat. Sementara, data penelitian ini adalah berupa variasi bahasa yang digunakan oleh pedagang kaki lima di Jalan Perjuangan, Kota Cirebon ketika melakukan transaksi jual beli saat berkomunaksi antara penjual dan pembeli. Kemudian, dihubungkan dengan penggunaan campur kode dan alih kode. Berdasarkan jenis variasi bahasa yang digunakan oleh pedang dan pembeli dapat diketahui penggunaan campur kode dan alih kode.

Adapun sumber penelitian yakni sumber dari pedagang kaki lima yang berada di Jalan Perjuangan, Kota Cirebon. Dengan jumlah 20 pedagang yang berada di sekitar UNSWAGATI, UNTAG, IAIN, dan STIKES Mahardika. Pemilihan subjek penelitian ini didasarkan atas beberapa hal, yaitu pertama faktor letak para pedagang berjualan, kedua tempat faktor penelitian berada dalam lingkungan kampus yang berada di sepanjang Jalan Perjuangan, Cirebon sehingga dapat menghasilkan sebuah penelitian berbasis lingkungan belajar.

\section{PEMBAHASAN}

Penelitian ini bertujuan untuk memperoleh data dan mendeskripsikan data tentang penggunaan campur kode dan alih kode bahasa dalam jual beli pada pedagang kaki lima di sekitar Jalan Perjuangan, dan mendeskripsikan seberapa penting campur kode dan alih kode dalam berkomunikasi, serta faktor-faktor yang menyebabkan alih kode dan campur kode yang terjadi pada interaksi jual beli pedagang kaki lima. Dari tujuan yang hendak dicapai tersebut, maka di 


\section{DEIKSIS - JURNAL PENDIDIKAN BAHASA DAN SASTRA INDONESIA}

butuhkan data penelitian berupa respon dari objek penelitian. Adapun yang dijadikan objek penelitian ini adalah pedagang kaki lima yang berada di sekitar Jalan Perjuangan, Cirebon berjumlah 20 pedagang, terdiri dari 4 tempat yang berbeda.

Dalam pengumpulan data peneliti merekam percakapan antara pedagang kaki lima dan pembeli dari semua tempat. Rekaman tersebut kemudian dialihkan oleh peneliti dari bentuk lisan kedalam bentuk tulis. Berdasarkan hasil penelitian yang telah dilaksanakan, peneliti memperoleh data berupa rekaman yang dilakukan oleh pembeli dan pedagang kaki lima. Dari hasil rekaman tersebut yang telah peneliti peroleh kemudian dilakukan perhitungan dan presentase dari setiap butir rekaman. Kemudian, berlanjut pada analisis dan simpulan akhir dari hasil rekaman tersebut. Adapun pengubahan data menjadi presentase dilakukan dengan cara menghitung jumlah pedagang kaki lima dibagi jumlah campur kode dan alih kode yang digunakan oleh pedagang dikalikan 100 .

\section{a. Data Respons Pedagang Kaki Lima di Jalan Perjuangan Sekitar UNSWAGATI, IAIN, UNTAG, STIKES MAHARDIKA terhadap Penggunaan Campur Kode}

Sebagaimana kita ketahui campur kode dan alih kode yang digunakan oleh para pedagang kaki lima dijalan perjuangan ini pada saat berkomunikasi dengan pembelinya bertujuan untuk membangun keakraban antara pedagang dan pembeli. Berdasarkan intensitas penggunaan campur kode dan alih kode dalam jual beli penulis mengklasifikasikan menjadi 4 kategori, yaitu : sering, agak sering, jarang, dan tidak pernah.

Tabel 4.1

Rekapitulasi Campur Kode Hasil Penyadapan pada Pedagang Kaki Lima di sekitar Jalan Perjuangan, Cirebon

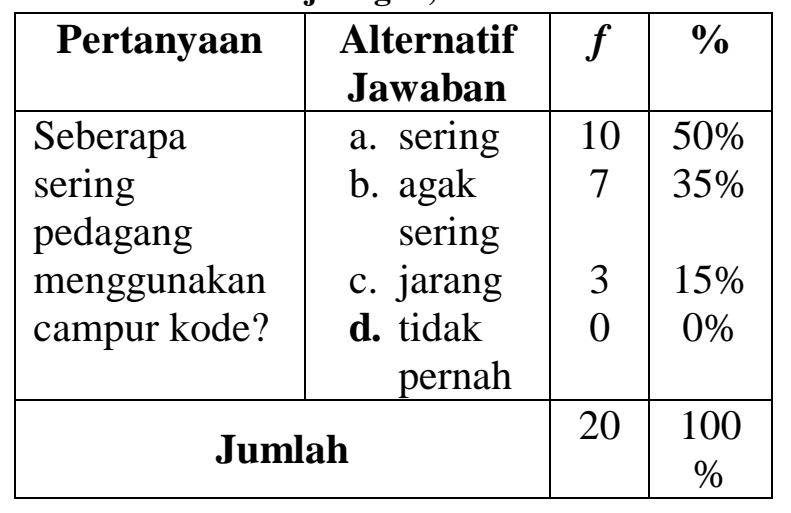

Berdasarkan data yang diporoleh dari hasil penyadapan kepada para pedagang yang berjumlah 20 orang ditemukan kategori sering dalam penggunaan campur kode 10 pedagang dari 20 atau 50\%, kategori agak sering dalam penggunaan campur kode terdapat 7 pedagang dari 20 atau $35 \%$, kategori jarang dalam penggunaan campur kode terdapat 3 pedagang dari 20 atau 15\%, kategori tidak pernah dalam penggunaan campur kode terdapat 0 pedagang dari 20 atau $0 \%$.

Berdasarkan penjelasan tersebut kita dapat mengetahui bahwa pedagang kaki lima di sekitar jalan perjuangan sering menggunakan campur kode dalam berinteraksi jual beli. Sebagaimana kita ketahui, campur kode dan alih kode yang digunakan oleh para pedagang kaki lima di Jalan Perjuangan, Cirebon ini pada saat berkomunikasi dengan pembelinya bertujuan untuk membangun keakraban antara 
pedagang dan pembeli. Berdasarkan intensitas penggunaan campur kode dan alih kode dalam jual beli penulis mengklasifikasikan menjadi 4 kategori, yaitu : sering, agak sering, jarang, dan tidak pernah.

Tabel 4.2

Rekapitulasi Campur Kode pada 20 Hasil Penyadapan Pedagang Kaki Lima di Sekitar Jalan Perjuangan, Cirebon

\begin{tabular}{|c|c|c|c|}
\hline Pertanyaan & $\begin{array}{l}\text { Alternatif } \\
\text { Jawaban }\end{array}$ & $f$ & $\%$ \\
\hline $\begin{array}{l}\text { Seberapa } \\
\text { sering } \\
\text { pedagang } \\
\text { menggunaka } \\
\text { n campur } \\
\text { kode? }\end{array}$ & $\begin{array}{l}\text { a. sering } \\
\text { b. agak } \\
\text { sering } \\
\text { c. jarang } \\
\text { d. tidak } \\
\text { pernah }\end{array}$ & $\begin{array}{l}10 \\
7 \\
3 \\
0\end{array}$ & $\begin{array}{c}50 \% \\
35 \% \\
15 \% \\
0 \%\end{array}$ \\
\hline \multicolumn{2}{|c|}{ Jumlah } & 20 & $\begin{array}{c}100 \\
\%\end{array}$ \\
\hline
\end{tabular}

Berdasarkan data yang diporoleh dari hasil penyadapan kepada para pedagang yang berjumlah 20 orang ditemukan kategori sering dalam penggunaan campur kode 10 pedagang dari 20 atau 50\%, kategori agak sering dalam penggunaan campur kode terdapat 7 pedagang dari 20 atau $35 \%$, kategori jarang dalam penggunaan campur kode terdapat 3 pedagang dari 20 atau 15\%, kategori tidak pernah dalam penggunaan campur kode terdapat 0 pedagang dari 20 atau $0 \%$. Berdasarkan penjelasan tersebut kita dapat mengetahui bahwa pedagang kaki lima di sekitar Jalan Perjuangan, Cirebon sering menggunakan campur kode dalam berinteraksi jual beli.

\section{b. Data Respons Pedagang Kaki Lima di Jalan Perjuangan Sekitar UNSWAGATI, IAIN, UNTAG, dan STIKES Mahardika Terhadap Penggunaan Alih Kode}

Sebagaimana kita ketahui, campur kode dan alih kode yang digunakan oleh para pedagang kaki lima di Jalan Perjuangan, Cirebon ini pada saat berkomunikasi dengan pembelinya bertujuan untuk membangun keakraban antara pedagang dan pembeli. Berdasarkan intensitas penggunaan campur kode dan alih kode dalam jual beli penulis mengklasifikasikan menjadi 4 kategori, yaitu : sering, agak sering, jarang, dan tidak pernah.

\section{Tabel 4.3}

Rekapitulasi Alih Kode pada 20 Hasil Penyadapan Pedagang Kaki Lima di Sekitar Jalan Perjuangan, Cirebon

\begin{tabular}{|c|c|c|c|}
\hline Pertanyaan & $\begin{array}{l}\text { Alternatif } \\
\text { Jawaban }\end{array}$ & $f$ & $\%$ \\
\hline Seberapa & a. sering & 15 & $50 \%$ \\
\hline sering & b. agak & 4 & $35 \%$ \\
\hline pedagang & sering & & \\
\hline menggunakan & c. jarang & 1 & $15 \%$ \\
\hline campur kode? & $\begin{array}{l}\text { d. tidak } \\
\text { pernah }\end{array}$ & 0 & $0 \%$ \\
\hline \multicolumn{2}{|c|}{ Jumlah } & 20 & $\begin{array}{c}100 \\
\%\end{array}$ \\
\hline
\end{tabular}

Berdasarkan data yang diporoleh dari hasil penyadapan kepada para pedagang yang berjumlah 20 orang ditemukan kategori sering dalam penggunaan alih kode 15 pedagang dari 20 atau $75 \%$, kategori agak sering dalam penggunaan alih kode terdapat 4 pedagang dari 20 atau 20\%, kategori 
jarang dalam penggunaan alih kode terdapat 1 pedagang dari 20 atau $5 \%$, kategori tidak pernah dalam penggunaan alih kode terdapat 0 pedagang dari 20 atau $0 \%$. Berdasarkan penjelasan tersebut, kita dapat mengetahui bahwa pedagang kaki lima di sekitar Jalan Perjuangan sering menggunakan alih kode dalam berinteraksi jual beli.

Tabel 4.4

\section{Rekapitulasi Makna Kosakata Campur Kode dan Alih Kode pada Pedagang Kaki Lima di Sekitar Jalan Perjuangan, Cirebon}

\begin{tabular}{|c|l|l|}
\hline No & $\begin{array}{c}\text { Kosakata } \\
\text { Campur } \\
\text { Kode }\end{array}$ & Makna \\
\hline 1 & Pedes & Pedas \\
\hline 2 & Teh & Kakak perempuan \\
\hline 3 & Sambel & Sambal \\
\hline 4 & Mas & Kakak Laki-Laki \\
\hline 5 & Pai & Kasih \\
\hline 6 & Neng & Sapaan kepada perempuan \\
& yang lebih muda \\
\hline 7 & Henteu & Tidak \\
\hline 8 & Beli & Tidak \\
\hline 9 & Uis & Sudah \\
\hline 10 & Depat & Sebentar \\
\hline 11 & Tas & Sudah \\
\hline 12 & Punten & Permisi \\
\hline 13 & Bengi & Malam \\
\hline 14 & Sing & Yang \\
\hline 15 & Kih & Ini \\
\hline
\end{tabular}

\begin{tabular}{|c|l|l|}
\hline 16 & Nok & $\begin{array}{l}\text { Sapaan kepada perempuan } \\
\text { yang lebih muda }\end{array}$ \\
\hline 17 & Nggo & Untuk \\
\hline 18 & Ngko & Nanti \\
\hline 19 & Dadi & Jadi \\
\hline 20 & Jumlahe & Jumlahnya \\
\hline 21 & Kelapae & Kelapane \\
\hline 22 & Dadak & Baru \\
\hline 23 & Gawe & Membuat \\
\hline 24 & Iki & Ini \\
\hline 25 & Gulae & Gulanya \\
\hline 26 & Ira & Kamu \\
\hline 27 & Maning & Lagi \\
\hline 28 & Klalen & Lupa \\
\hline 29 & Mene & Kemari \\
\hline
\end{tabular}

Berdasarkan hasil data yang sudah direkap dengan melakukan penelitian menggunakan teknik penyadapan, dari dua puluh pedagang yang telah kami sadap dari empat tempat yang berbeda yaitu pedagang kaki lima di lingkungan UNSWAGATI, IAIN, UNTAG, serta STIKES Mahardika. Oleh karena itu, dapat disimpulkan bahwa hasil data tabel di atas hampir keseluruhan pedagang kaki lima menggunakan campur kode dalam percakapan dengan pembeli. Bahasa-bahasa tersebut merupakan hasil dari pengamatan dan sering tidaknya digunakan dalam berinteraksi.

Kosakata seperti pedes, mene, bengi, tuku, dan maning hampir semua pedagang kaki lima menggunakan kata tersebut. Hal ini dibuktikan dengan dua puluh responden 


\section{DEIKSIS - JURNAL PENDIDIKAN BAHASA DAN SASTRA INDONESIA}

dari setiap tempat yang berbeda yang telah kami sadap dan semuanya hampir menggunakan atau memakai kosa kata tersebut. Hal ini dapat terjadi oleh setiap insan yang menggunakan bahasa Indonesia sebagai bahasa pemersatu dan bahasa ibu sebagai bahasa yang pertamakali dipelajari. Oleh karena itu, penggunaan campur kode dikalangan pedagang kaki lima sangat umum terjadi.

\section{c. Interpretasi Hasil Penelitian}

Pada suatu aktivitas bicara yang terjadi dalam kehidupan sehari-hari, seseorang yang melakukan pembicaraan sebenarnya mengirimkan kode-kode kepada lawan bicaranya (Pateda dalam Achmad da Alex, 2011: 16). Pengkodean melalui proses yang terjadi baik kepada pembicara maupun mitra bicara. Fenomena ini terjadi pada pedagang kaki lima di sekitar jalan Perjuangan Cirebon. Pada umumnya, saat berkomunikasi dengan pembeli mereka sering menggunakan campur kode dan alih kode karena bertujuan agar terjalin keakraban dengan pembeli pada saat interaksi jual beli berlangsung.

Berdasarkan hasil observasi serta penyadapan atau merekam pada pedagang kaki lima di sekitar Jalan Perjuangan, Cirebon, menggunakan campur kode dan alih kode tersebut hanya digunakan pada saat berkomunikasi antara pedagang dan pembeli saja. Dilingkungan keluarga, mereka lebih cenderung menggunakan bahasa tutur yang didapat dari lingkungan sekitar. Penggunaan campur kode dan alih kode dalam percakapan antara penjual dan pembeli berfungsi sebagai pengakrab dan mempermudah dalam berkomunikasi. Dengan demikian, campur kode dan alih kode dapat diartikan sebagai bahasa yang umum digunakan pada saat situasi non formal (santai). Adapun penggunaan bahasa gaul dalam berkomunikasi disesuaikan dengan lawan tuturnya yaitu pembeli.

\section{E. SIMPULAN}

Berdasarkan hasil penelitian yang telah dipaparkan di atas, maka dapat diambil kesimpulan, bahwa kegiatan tindak bahasa campur kode oleh masyarakat hampir setiap hari, bahkan dalam setiap aktivitas dalam kehidupan sehari-hari dapat terjadi. Sehingga, dapat dikatakan bahwa campur kode ialah hal yang biasa dilakukan oleh masyarakat dalam berkomunikasi.

Berdasarkan data yang ada ternyata tuturan para pedagang di sekitar Jalan Perjuangan Cirebon khususnya dilingkungan kampus 2 UNSWAGATI, kampus UNTAG, kampus IAIN, serta kampus STIKES Mahardika termasuk penutur yang bilingual. Penutur yang bilingual menyebabkan terjadinya campur kode bahasa daerah dengan bahasa Indonesia di lingkungan sekitar Jalan Perjuangan, Cirebon. Campur kode yang terjadi dalam situasi nonformal pada saat interaksi jual beli untuk lebih akrab dengan pembeli serta menegaskan informan dalam berkomunikasi antar penutur, dapat disebut juga pedagang dan pembeli. Bentuk campur kode dalam peristiwa komunikasi antara pedagang dengan pembeli di lingkungan sekitar Jalan Perjuangan Cirebon berupa:

1) campur kode bentuk kata;

2) campur kode bentuk frasa; dan 


\section{DEIKSIS - JURNAL PENDIDIKAN BAHASA DAN SASTRA INDONESIA}

3) campur kode bentuk klausa.

Adapun faktor-faktor penyebab terjadinya campur kode yaitu persamaan latar belakang bahasa dan budaya atau bahasa ibu, perbedaan latar belakang bahasa dan budaya atau bahasa ibu, tetapi mereka mengerti komunikasi dalam latar belakang tiga bahasa ibu yang berbeda, ingin mudah dipahami dan memahami, serta faktor kebiasaan menggunakan bahasa daerah dan lingkungan yang sama.

Kebebasan penggunaan bahasa yang dilakukan oleh penutur atau pedagang dengan lawan tutur atau pembeli diatas semata-mata dilakukan dengan faktor ketidaksengajaan. Percampuran bahasa dilakukan karena dilatarbelakangi oleh situasi dan penutur yang sama-sama berasal dari suatu daerah yang sama. Berdasarkan rumusan masalah diatas maka dapat disimpulkan bahwa, kode yang digunakan para pedagang kaki lima dilingkungan sekitar Jalan Perjuangan, Cirebon ketika berkomunikasi tergantung situasi dan siapa lawan tutur. Seperti halnya pada percakapan diatas, terkadang para pedagang kaki lima menyelipkan atau mencampurkan serpihanserpihan bahasa daerah. Hal ini disebabkan oleh lingkungan sekitar dan tempat tinggalnya yang mengakibatkan terjadinya alih kode dan campur kode bahasa.

\section{F. DAFTAR PUSTAKA}

Achmad dan Alex. (2011). Linguistik Umum. Jakarta: Erlangga.

Chaer, Abdul dn Leonie Agustina. (2009). Sosionguistik Perkenalan Awal. Jakarta: Rineka Cipta.
Kridalaksana, Harimurti.(1987). Fungsi Bahasa dan Sikap Bahasa. Jakarta: Nusa Indah.

Kridalaksana, Harimurti. (2011). Kamus Linguistik. Jakarta: Gramedia Pustaka Utama.

Sudaranto. (1993). Metode dan Aneka Teknik Analisis Bahasa, Pengantar Penelitian Wahana Kebudayaan Secara Linguistik. Yogyakarta: Duta Wacana.

Sumarsono. (2009). Sosiolinguistik. Yogyakarta: Sabda.

Suwito. (1985). Pengantar Awal Sosiolinguistik: Teori dan Problema. Surakarta: Henry Offset. 